USAWC STRATEGY RESEARCH PROJECT

\title{
CHANGING JAPAN'S NATIONAL SECURITY STRATEGY: IS IT IN JAPAN'S INTEREST?
}

\author{
by \\ Mr. Brett A. Miller \\ National Security Agency
}

Colonel Jiyul Kim
Project Adviser

This SRP is submitted in partial fulfillment of the requirements of the Master of Strategic Studies Degree. The U.S. Army War College is accredited by the Commission on Higher Education of the Middle States Association of Colleges and Schools, 3624 Market Street, Philadelphia, PA 19104, (215) 662-5606. The Commission on Higher Education is an institutional accrediting agency recognized by the U.S. Secretary of Education and the Council for Higher Education Accreditation.

The views expressed in this student academic research paper are those of the author and do not reflect the official policy or position of the Department of the Army, Department of Defense, or the U.S. Government. 


\section{Report Documentation Page}

Form Approved

OMB No. 0704-0188

Public reporting burden for the collection of information is estimated to average 1 hour per response, including the time for reviewing instructions, searching existing data sources, gathering and maintaining the data needed, and completing and reviewing the collection of information. Send comments regarding this burden estimate or any other aspect of this collection of information,

including suggestions for reducing this burden, to Washington Headquarters Services, Directorate for Information Operations and Reports, 1215 Jefferson Davis Highway, Suite 1204, Arlington

VA 22202-4302. Respondents should be aware that notwithstanding any other provision of law, no person shall be subject to a penalty for failing to comply with a collection of information if it

does not display a currently valid OMB control number.

1. REPORT DATE

30 MAR 2007

4. TITLE AND SUBTITLE

Changing Japan's National Security Strategy Is It In Japan's Interest

6. AUTHOR(S)

Brett Miller

7. PERFORMING ORGANIZATION NAME(S) AND ADDRESS(ES)

U.S. Army War College,Carlisle Barracks,Carlisle,PA,17013-5050

9. SPONSORING/MONITORING AGENCY NAME(S) AND ADDRESS(ES)
2. REPORT TYPE

Strategy Research Project
00-00-2006 to 00-00-2007
3. DATES COVERED

5a. CONTRACT NUMBER

5b. GRANT NUMBER

5c. PROGRAM ELEMENT NUMBER

5d. PROJECT NUMBER

5e. TASK NUMBER

5f. WORK UNIT NUMBER

8. PERFORMING ORGANIZATION

REPORT NUMBER

10. SPONSOR/MONITOR'S ACRONYM(S)

11. SPONSOR/MONITOR'S REPORT

NUMBER(S)

12. DISTRIBUTION/AVAILABILITY STATEMENT

Approved for public release; distribution unlimited

13. SUPPLEMENTARY NOTES

14. ABSTRACT

See attached.

15. SUBJECT TERMS

16. SECURITY CLASSIFICATION OF:

a. REPORT

unclassified b. ABSTRACT

unclassified c. THIS PAGE unclassified
17. LIMITATION OF ABSTRACT

\begin{tabular}{|l|l}
$\begin{array}{c}\text { 18. NUMBER } \\
\text { OF PAGES }\end{array}$ & 19a. NAME OF \\
$\mathbf{2 0}$ & RESPONSIBLE PERSON \\
&
\end{tabular}




\section{ABSTRACT}

\begin{tabular}{ll} 
| AUTHOR: & Mr. Brett A. Miller \\
\hline TITLE: & Changing Japan's National Security Strategy: Is It in Japan's Interest? \\
FORMAT: & Strategy Research Project \\
DATE: & 1 February 2007 WORD COUNT: $5538 \quad$ PAGES: 20 \\
KEY TERMS: & Article 9, Constitution \\
CLASSIFICATION: & Unclassified
\end{tabular}

For more than 60 years, since the end of World War II, there has been a widely shared public consensus in Japan that the Japanese government should abide by the pacifistic guidelines decreed by its constitution. Since the end of WWII, Japan has remained at peace due to constitutional restrictions, the vigilance of its peace movement, and the commitment of the United States to provide for its security. Collectively these factors have enabled Japan to focus on economic initiatives thus creating a new model of a major power whose economic power was not matched by its military might. Today, Japan is under immense pressure from the United States to shoulder more of the burden of its own security and participate in the preservation of peace throughout the world. This paper will investigate whether a change to Japan's national security strategy is in its best interest. In particular, this paper will examine the current political climate (both domestically and abroad) and discuss the potential concerns to the revision of the constitution. Additionally, this paper will investigate the potential for other alternatives for changing Japan's strategic doctrine. Finally, a way forward for Japan's national security strategy will be recommended. 



\section{CHANGING JAPAN'S NATIONAL SECURITY STRATEGY: IS IT IN JAPAN'S INTEREST?}

Since the 1950s, Japan has been closely allied with and reliant upon the United States (U.S.), which has taken responsibility for a significant portion of the country's overall defense. As it currently exists, the Japanese constitution prohibits the maintenance of a traditional military or use of force for any other purpose than self-defense. ${ }^{1}$ Since 1954, while maintaining a self defense force, Japan has permitted the United States to maintain military bases on Japanese soil in exchange for a guarantee of security. ${ }^{2}$

Over 50 years later, more than 50,000 U.S. military personnel are still stationed in Japan, helping to preserve peace not only in Japan, but throughout the Pacific. ${ }^{3}$ Now, for the first time, Japan's pacifistic constitution, known as the "peace constitution," faces the real possibility of revision. But if Japan was to revise its constitution, what potential political pitfalls would exist? China and Korea (among other Asian nations) are certainly following closely developments on the debate of constitutional change. Not only are there political issues for Japan, but also for the United States, as there is growing U.S. concern that the already chilly relations between Japan and its neighbors may erode, affecting U.S. interests in the region. ${ }^{4}$ Is a revised constitution in the best interests of Japan? If so, what measures could be taken to limit the political backlash that may be encountered? And what issues, domestically, may or may not have an impact on Japan's constitutional revision? Today, Japan's approach to military strategy is to develop capabilities that will not be considered offensive in nature. This certainly has the potential to change if the constitution were to be revised. Certainly a number of countries throughout the region will take notice, even though a change to the constitution does not mean Japan will inevitably make changes to its national security strategy. Are there alternatives for Japan to consider that would meet its needs without forcing its leaders to change the country's constitution?

The Japanese public consensus has widely supported maintaining its peace constitution since the end of World War II. ${ }^{5}$ This consensus, along with constitutional restrictions and the vigilance of the peace movement, has enabled Japan to remain at peace. ${ }^{6}$ Furthermore, U.S.'s security guarantee has enabled Japan to focus on the economy, thus creating a new model for a major power whose economic power is not matched by its military capabilities. This paper will investigate whether a change to Japan's national security strategy is in its best interest. In particular, this paper will examine the current political climate (both domestic and abroad) and discuss the potential concerns regarding constitutional revision. Additionally, this paper will 
investigate the potential for other alternatives in changing Japan's security strategy. Finally, a way forward for Japan's national security strategy will be recommended.

\section{Background}

Since the end of World War II Japan has maintained a pacifistic stance that has shunned the idea of the use of violence. Stipulated in Article 9 of the Japanese constitution is the prohibition against maintaining a military or using force for purposes other than defense. ${ }^{7}$ In 1954, the United States and Japan signed the Mutual Defense Treaty that committed the U.S. to the defense of Japan in return for the right to station military forces on Japanese territory. ${ }^{8}$

The security treaty clearly benefited both nations. Japan was provided security, enabling it to focus on the rebuilding of its economy. The Japanese Prime Minister at the time, Yoshida Shigeru, considered economic recovery Japan's highest priority. This policy was pursued by all successive administrations that made the size of the Japanese economy second only to the U.S. by the 1980 s although it now ranks third. ${ }^{9}$ The United States used the treaty to counter the growing threat of the Soviet Union and the spreading of communism. ${ }^{10}$ In 1960 , a new treaty was signed in which Japan assumed responsibility for ensuring its own internal security while the United States agreed to join in its defense in the event of an attack from outside forces. ${ }^{11}$

Japan has not always enjoyed the ties to the west that it does today. Starting in the 1600's, the Shogun Tokugawa leyasu (1604-1651), instituted a policy of "seclusion" that forbade citizens from traveling abroad and allowed for only extremely limited trade. ${ }^{12}$ External factors, however, eventually forced great changes upon the country. In 1853, the arrival of Commodore Matthew Perry, who threatened Japan with war if it did not agree to trade, forced the country to reevaluate itself. From that point forward, Japan slowly began opening up to international trade. ${ }^{13}$ The circumstances by which trade eventually became standard practice however, were not necessarily voluntary. ${ }^{14}$ Much like other Asian nations, the Japanese were forced to agree to trade treaties with the western powers. ${ }^{15}$ These trade agreements that imposed a semicolonial status upon Japan, led in part to the fall of the Tokugawa and the restoration of the Emperor Meiji. ${ }^{16}$ The early years of the Meiji period brought revolutionary changes including the modernization of the educational system, return of land to the central government, institution of conscription, creation of modern national Army and Navy, improvement to transportation and communication systems, creation of a central bank, and development of a Western-style constitution. $^{17}$

During the 1930s, the Japanese military began its rise to power, eventually leading to its full control of the government. ${ }^{18}$ In doing so, the Japanese leadership continued the 
expansionistic policies it had adopted during the Meiji period. It was these polices, along with the American led international embargo in response to the invasion of China, that resulted in the Japanese attack on the United States at Pearl Harbor. ${ }^{19}$

Japan's defeat in World War II meant the demise of the Japanese military. A new constitution, adopted in 1947, forbade Japan from maintaining a military and made war, as an instrument of official policy, illegal. ${ }^{20}$ Specifically, Article 9 of the Japanese constitution stipulated that the Japanese people "forever renounce war as a sovereign right of the nation and the threat or use of force as means of settling international disputes."21 Many Japanese consider this Japan's pledge to the world that a conflict such as World War II in the Pacific will never take place again. ${ }^{22}$ Or at least it will not be started by Japan.

\section{A Larger International Role For Japan}

The policies pursued by Japan today originate from the core values and ideas contained in its constitution. Outlined in the constitution's preface, these values and ideas define the national purpose of Japan as securing peaceful cooperation with all nations, never again facing war due to its own actions, preserving its own security and existence, and eliminating tyranny, slavery, oppression, and intolerance from the world. ${ }^{23}$ The security policy of Japan is based on its determination to "preserve its security and existence," which can be summed up as ensuring peace and prosperity for Japan and its citizens. Abiding by its self-imposed abstention from the threat or use of military force in the settlement of international disputes, Japan has actively worked to ensure its security through the promotion of peace and prosperity in the world through the use of diplomatic, economic and the financial aspects of its national power. It is Japan's use of these aspects of national power that enables it to focus on maintaining its passive defense strategy. Still, many argue for a change to Article 9 of the constitution that would permit Japan to maintain a military for other than strict self-defense purposes including the projection of a deterrence capability.

This internal debate taking place on the revision of the constitution has the world watching intently. Japan's current constitution is synonymous with its post World War II defense policy. ${ }^{24}$ A change to the constitution clearly allowing the existence of a military would be viewed by the world as a change to Japan's defense strategy. The reality however, is that Japan currently has one of the most modernly equipped militaries in the world, the Japanese Self-Defense Force (JSDF). ${ }^{25}$ The amount of money Japan spends on its Self-Defense Force is in the neighborhood of $\$ 45$ billion a year, double the military spending of all countries in the Pacific 
region with the exception of China. ${ }^{26}$ The JSDF currently has more than 240,000 personnel assigned to air, sea and land forces. ${ }^{27}$

Why the concern among its neighbors if Japan has maintained the JSDF since 1954? The change to the constitution evokes the perception that Japan is making a change to its view of the military as an instrument of national power. This conjures memories of the militarism of 1930s and 40s Japan. War- time history continues to impact the relationship between Japan, and South Korea and China today, but significant changes have taken place in the world since the adoption of the Japanese constitution in $1947 .{ }^{28}$ Although the historical aspects of Japan's militarism cannot be denied, for the past sixty years Japan has demonstrated that its national security strategy is based on its core values and ideas outlined in its constitution. A change to the constitution allowing for explicitly maintaining a military is not a sign of a resurgence of Japanese militarism nor is it a reversion to its expansionistic policies. A change to the Japanese constitution would be a measure by Japan to maintain pace within an ever changing world order.

Simply put, there is no one factor that can be attributed to Japan's recently increased consideration for making changes to its constitution. Driving forces for change are both internal and external. The question remains, however, as to whether any of these forces are powerful enough to propel Japan to change its constitution and allow for a new strategy to be considered in ensuring its security. One major factor that plays into Japan's consideration for constitutional revision is its desire to obtain a seat on the United Nations Security Council. ${ }^{29}$ Secretary of State Colin Powell stated, "If Japan is going to play a full role on the world stage and become a full active participating member of the Security Council, and have the kind of obligations that it would pick up as a member of the Security Council, Article Nine would have to be examined in that light." ${ }^{130}$ Clearly this statement by the senior diplomat of the U.S. is a potential indication of what it will take for Japan to obtain U.S. support in the United Nations. Japan's role in the international community has continued to grow in terms of both contributions of personnel and monetary support. Currently, Japan is the second largest contributor of funds to the United Nations behind the United States. ${ }^{31}$ Likewise, its contributions to the International Monetary Fund and its official overseas development assistance are second only to the amount contributed by the United States. ${ }^{32}$ However, its past practice of contributing only funds and not troops in support of international initiatives has resulted in criticisms that it is exercising "Checkbook Diplomacy."33

Japan has taken steps to shed its image of checkbook diplomacy by providing personnel in support of the Global War on Terrorism. Although not involved in military operations, the 
JSDF provided personnel for humanitarian and reconstruction missions in Iraq, deployments that ended on July 17, 2006 after two and a half years. ${ }^{34}$ Although there were critics within Japan on the decision to deploy troops to Iraq, a recent survey showed that $60 \%$ of the Japanese population believed it was the right decision. ${ }^{35}$ This significant show of support by the Japanese population is not inconsequential. The country's decision to deploy personnel was a step toward Japan playing a larger role in security efforts. This is clearly the direction that the United States would like to see Japan move towards, although it would like to see Japan take on an even larger role than simply partaking in peacekeeping or nation building.

\section{Existing Regional Issues}

On the domestic front, Japan's leadership is feeling pressure to revise the constitution. The length of time that has elapsed since World War II has many Japanese believing that the country should stop acting like the defeated country it was sixty years ago. ${ }^{36}$ This sentiment is strengthened by a number of regional issues that continue to foster concern among the Japanese. The current and ongoing buildup of the Chinese military is one such example. ${ }^{37}$ Compounded by North Korea and the inflammatory rhetoric by its leader Kim Jong-II, the buildup of the Chinese military has the Japanese populace on an edge. ${ }^{38}$ This concern, however, is not only on the part of the Japanese. An ongoing controversy in the region has Korea and China focused on Japan's portrayal of its own actions during the Korean colonial period and up to and throughout the Second World War. ${ }^{39}$ Korea and China each claim that the portrayals depicted in Japanese textbooks present a distorted view of history. ${ }^{40}$ Issues such as Japan's downplaying of its expansionistic policies while focusing on its aim of liberating the former Asian colonies from western domination and reducing or eliminating mention of its own colonial ambitions have the two countries believing that Japan has not atoned for its actions prior to and during the Second World War. ${ }^{41}$

Relations with these countries have been strained in the recent past primarily due to former Prime Minister Koizumi's visits to the Yasukuni Shrine. Public opinion is split equally on whether or not a sitting Japanese Prime Minister should visit the shrine that memorializes the war dead, including Class A war criminals from World War II. ${ }^{42}$ There is recognition among the people, however, that strained relations between Japan and the two other countries do in fact exist. In an October 2005 poll conducted by the Japanese Cabinet Office, almost 20\% believed that Japan had "good" or "somewhat good" relations with China while over $71 \%$ believed that relations between the two countries were either "not so good" or "not good." The same poll showed that while over $40 \%$ believed that relations between Japan and Korea were "good" or 
"somewhat good," nearly 51\% believed that relations were "not so good" or "not good."43 Although it has been over 60 years since the end of Japan's militarism, those countries that have experienced Japan's military aggression remain concerned about a return to the militarism of pre-WWII Japan. ${ }^{44}$ The past deeds committed by Japan towards its neighbors, along with the possibility of a revision to its constitution, have caused countries throughout the region to take notice. $^{45}$

If the past was the sole indicator of the future, clearly Japan's neighbors would have cause for concern. From 1895 - 1945, Japan occupied the Island of Taiwan, invaded Manchuria, attacked Pearl Harbor, and colonized the Korean peninsula (1910-1945). ${ }^{46}$ Japan's use of the Taiwanese and Koreans as "slave labor" as well as the atrocities it committed against China are well documented. For seven weeks in 1937 Japanese troops murdered and raped tens of thousands of people in what has become known as the Nanjing Massacre. ${ }^{47}$ Although the final body count is in dispute, (China claims 350,000 people were murdered while Japan claims the number is closer to 40,000 ), there is no dispute on whether these brutal murders and rapes took place. ${ }^{48}$ Among those who have experienced Japan's aggressiveness, lingering concerns are certainly understandable. The younger generations, however, have only known a peaceful Japan.

There are times when progress seems to be made only to be set back again by the actions of Japan. During Prime Minister Koiziumi's visit to the Republic of Korea's capital in June of 2005, it seemed that progress was being achieved in alleviating tensions brought on by Japan's past atrocities. ${ }^{49}$ While meeting with Prime Minister Koizumi, South Korean President Roh Moo Hyun recommended that Japan build a secular war memorial to alleviate the hateful feelings brought on by the visits to Yasukuni Shrine. ${ }^{50}$ Additionally the two countries agreed to work together to investigate the historical aspects of the atrocities Japan committed during its colonization of Korea, and Japan made a commitment to investigate whether or not South Koreans were brought to Japan during World War II and forced into slave labor ${ }^{51}$

On the surface, these exchanges and agreements seemed to be a step in the right direction, particularly since a similar strategy had worked for the French and Germans after World War II. ${ }^{52}$ In 1950, both the French and Germans met with groups of historians and teachers to discuss ways of dealing with the historical aspects of the Second World War; they agreed that history should be written into their textbooks to ensure that World War II would never be forgotten. Similarly, West Germany worked with Poland to discuss how best to address the issue and collectively published guidelines on their common interpretation of the war. ${ }^{53}$ Clearly, the agreement between Japan and South Korea to investigate the disputed 
history between the two countries was a step in the right direction. ${ }^{54}$ However, Prime Minister Koizumi's visit to Yasukuni Shrine in August of 2005 evoked outcries from China and the two Koreas and scuttled the progress that had been made between Japan and South Korea. ${ }^{55}$ Apologizing for its atrocities and taking steps to avoid stirring feelings of the past would go a long way to improving Japan's relationships throughout the region. However, there are other issues that need addressed as well. A long-standing dispute between Japan and South Korea has existed over the ownership of a group of islands located in the Sea of Japan / East Sea. This issue arose again in February 2005, when the Japanese ambassador to the Republic of Korea claimed Japanese sovereignty over the islands. ${ }^{56}$ Ironically, this took place during the first Korea - Japan Friendship Year in celebration of the $40^{\text {th }}$ anniversary of the establishment of diplomatic relations between the two countries. ${ }^{57}$

\section{$\underline{\text { Rise of China as a International Power }}$}

Similar feelings exist in China with regards to sentiments that Japan glorifies its past when the Prime Minister visits Yasukuni Shrine. ${ }^{58}$ The tumultuous relationship between the two countries and the recent buildup of the Chinese military has created a major spark to the debate of a constitution revision. For most of the post-war era, the Chinese believed that Japan was focusing on the advancement of it economy posing no strategic threat in the region. ${ }^{59}$ This was reinforced by Japan's pacifist constitution. At the same time, the Japanese believed that China relied on its trade with Japan which it believes gave it the upper hand in the region due to its more advanced economy. ${ }^{60}$ However, the buildup of Japan's Self-Defense Forces, along with the rise of the Chinese economy, has caused each country to reconsider the methods by which it exports influence throughout the region. For instance, in 2005, the Chinese led an organized opposition against Japan's bid for a seat on the UN Security Council to prevent Japan from gaining additional influence throughout the region. ${ }^{61}$

The ongoing Chinese military buildup has the potential to threaten the regions balance of power. ${ }^{62}$ According to Peter Rodman, Assistant Secretary of Defense for International Security Affairs, "China has more than 700 short-range ballistic missiles aimed at Taiwan, with the numbers increasing at about 100 missiles a year." ${ }^{63}$ This posture is a significant change from just a few years prior when there were no known missiles aimed at Taiwan. ${ }^{64}$ Is the Chinese buildup due only to the situation with Taiwan or does China have larger ambitions? Much of the concern amongst the Japanese stems from not knowing China's true intentions. Although China claims that the ongoing buildup is for strictly peaceful purposes, the world has watched it continually increase its military spending over the last 10 years. ${ }^{65}$ From $1994-2004$, China 
averaged a 16\% yearly increase in military spending and is now dedicating $\$ 80$ billion per year to build its strategic and conventional military capabilities. ${ }^{66}$ This increase comes with a lack of rationale or reasoning for such a buildup, leaving Japan and other countries throughout the region taking notice and expressing clear concerns. Moreover, experts claim that the Chinese military, with over 2.3 million people, could potentially challenge the power of the United States. ${ }^{67}$

\section{An Arms Race in the Making?}

Recent developments in the region may have accelerated the debate in Japan on amending the constitution. On October 9, 2006, North Korea's Korean Central News Agency announced that it had successfully conducted an underground nuclear test. ${ }^{68}$ This could potentially cause significant ramifications throughout the region. ${ }^{69}$ Japan has a significantly modernized nuclear power program and although it is for peaceful purposes, with its experience in the nuclear industry and stockpile of useable plutonium, Japan could manufacture a nuclear weapon within a year's time. ${ }^{70}$

In the past, Japan has taken defense measures when a potential threat to its security was posed by the North Korean regime. In 1998, North Korea fired a Taepo-Dong missile over northern Japan, with the missile landing a few hundred kilometers off the Japanese mainland in the Pacific Ocean. ${ }^{71}$ In response, Japan took measures to implement a missile defense system, outlining plans to jointly develop a new generation missile defense system with the United States. ${ }^{72}$ A move by Japan to develop its own nuclear capability could see the region faced with a nuclear arms race comparable to that between the U.S. and the USSR during the Cold War. Due to continuing poor relations with Japan, both China and South Korea would be expected to take measures to counter a nuclear Japan. Although China is already in possession of nuclear weapons, its emphasis would be placed on countering the Japanese threat, potentially leading to a relationship similar to that of the United States and the Soviet Union during the Cold War. Similarly, South Korea, which is currently not in possession of nuclear weapons, would possibly take steps to counter the nuclear threat of Japan. This scenario is certainly not out of the realm of possibility. A recent revelation by the South Korean government indicated that scientists had conducted two separate nuclear experiments in 1982 and $2000 .^{73}$

\section{An Opportunity to Set a Moral Example}

Clearly, the current environment throughout the region is extremely complicated. The internal debate taking place in Japan today regarding the constitution includes many factors from both the past and present that must be taken into consideration. The countries past 
aggressions have prevented good relations with the other economic and military powers of the region, in particular China and South Korea. The lack of good relations between Japan, South Korea, and China, however, has not previously carried the importance that it does today. The ongoing buildup of the Chinese military, along with the emergence of its economy, the recent testing of a nuclear weapon by North Korea, and the past atrocities committed against Korea, could easily force a rapid degradation in relations throughout the region. Today, Japan has the opportunity to lead by example and ensure stability throughout the region. The challenge for Japan is the balancing of its security while maintaining regional stability. On one hand if Japan were to change its constitution the perception of a return to militarism without agreeing on how history should be portrayed has the potential to destabilize the region. On the other hand, Japan's desire to obtain a permanent seat on the United Nations Security Council, the ongoing buildup of the Chinese military, and the North Korean threat have increased internal pressure in favor of constitutional reform.

Although internal pressure is mounting what Japan should not do, is make a change to Article 9 of its constitution. The renouncement of war by Japan is a significant aspect of what makes Japan what it is today. Naturally, the Japanese people will have the ultimate say on whether the article renouncing war is modified, but Japan's focus on the use of economic, diplomatic and the financial aspects of power to "preserve its security and existence" has been a very successful strategy. What is needed to address the current conditions in the region, however, is a change in the security strategy with respect to the non-military elements of national power.

As part of the diplomatic aspect of its security strategy, Japan must atone for its past aggressions. This includes working collectively with those countries that it has committed crimes against and negotiating an agreement on how that history should be remembered. This would entail taking proactive measures to educate its citizens and particularly its youth on the country's history to insure that its past deeds will always be remembered. But most importantly, as progress through diplomatic measures is made, Japan must ensure that its actions do not speak differently than its words and that degradation to relations is not caused by insensitive actions, such as its Prime Minister visiting the Yasukuni Shrine. Clearly, Japan has demonstrated its desire for a peaceful world through its actions and renouncement of war over the past sixty years and it now has the opportunity to enhance this statement for peace by owning up to the past and taking the necessary actions to put this period to rest. Certainly, this is not an easy thing for a country to do and some may say that asking the Japanese to take these steps is unrealistic. However, taking this approach will allow it to lay the groundwork for a 
peaceful region built on the framework of trust. The trust and confidence developed amongst these countries will enable a frank discussion regarding the other issues affecting Japan's relationships with its neighbors, such as the dispute over the Islands in the Sea of Japan. However, until the issue regarding the past atrocities can be rectified, other ongoing disputes will continue to linger and progress on creating a mutual relationship built on trust and respect will be prevented.

Another focus should be on increasing its support to developing countries throughout the world in the form of aid and assistance. As the second largest contributor of aid to those countries in need, Japan should certainly be commended. However, increasing its support for these countries in need enables Japan to assist in developing a more peaceful and safer world and provides for establishing better diplomatic and hopefully economic ties with these particular countries. Japan has been a world leader in providing humanitarian aid and should continue to make this area a significant aspect of its security strategy.

To enable Japan the ability to obtain maximum return on its investment in the diplomatic arena, it should increase its intelligence gathering capabilities. Japan is a technologically adept country that has the capability to create a significant and sizable intelligence gathering apparatus. An enhanced ability in the intelligence arena will provide Japan with the upper hand in its diplomatic negotiations and enable it to more effectively protect its interests throughout the world. Likewise, the ability of Japan to maintain a situational awareness of not only its region but also the world in general will enable it to maneuver more agilely in the diplomatic and economic arenas. This is a potential area for partnership with the United States as it looks to Japan to play a larger role in the region's security.

Japan should continue to focus on its alliance with the United States as a major part of its overall national security strategy. The benefits that each country receives from this strategic partnership are clear and the fostering of this alliance should not only be a focus for Japan but the United States as well. The ongoing buildup of the Chinese military and the rhetoric and recent testing of a nuclear weapon by North Korea dictate that an ongoing alliance is necessary to maintain a balance of power throughout the region. This is particularly true if China's economy continues to grow at an increased rate, thus giving it the capability and resources to continue with the buildup of its military. Recently, in response to North Korea's nuclear testing, the United States confirmed its commitment to the defense of Japan. Secretary of State Condelezza Rice reassured Japan that the United States would continue providing for its security on October 18,2006 , stating, "the United States has the will and the capability to meet 
the full range - and I underscore - the full range of its deterrent and security commitments to Japan."74

Japan should continue to use its Self-Defense Forces to participate in peacekeeping missions and nation building. The participation of the JSDF in peacekeeping and humanitarian initiatives clearly has the backing of the Japanese populace as demonstrated by the $60 \%$ approval rating for the JSDF participation in the rebuilding of Iraq. The increased participation of the JSDF in these types of engagements could be accomplished either by a reinterpretation of the constitution or by the passing of new laws that permit Japan to participate in humanitarian or nation building initiatives even when they take place in war zones. JSDF deployments have previously required action by the Japanese Diet and have been limited to fairly short periods of time. As required, the Diet took action to extend the JSDF deployments but if Diet concurrence for UN peacekeeping or international humanitarian operations continues to be required, the potential exists that legal maneuvers would significantly impact Japan's ability to participate and contribute to international security. Japan should take action by passing a law that provides the Prime Minister with the capability to deploy Japanese troops to support humanitarian and peacekeeping operations. As Japan would continue to rely on the United States for its security in this scenario, Japan would naturally need to work on identifying the expectations and circumstances under which it would provide troops to support international initiatives.

Taking the above-mentioned steps can produce a great effect on the future of Japan's national security strategy. Relying on the United States for security, even on a reduced scale, should not, however, be Japan's sole focus for security. Its pacifistic constitution and the focus on its economy have served it well over the past 60 years. Japan should continue to rely on its contribution to the international community while also utilizing the coercive capabilities of its diplomatic, financial and economic strength to further its own security. An enhanced intelligence gathering capability will enable Japan to more effectively wield these non-military instruments of national power and ensure its national interests.

Most important, however, is that in order to maintain stability in the region and the greater world, Japan should refrain from making changes to its constitution, particularly Article 9 that would allow for first-strike or offensive military capability. Japan should continue the development of those capabilities that are not considered offensive in nature. Continuing its reliance on the United States for military support in the event of an attack from external entities while building up the capabilities of its Self-Defense Forces (for strictly defense purposes) and maintaining its efforts to contribute to the overall welfare of the international community either through financial means, diplomatic assistance, or participation in peacekeeping and 
humanitarian initiatives will enable Japan to attain the world status that it seeks. In fact, by taking the route suggested, the potential exists that Japan may obtain a position of power more influential than that which it seeks. Much of the animosity towards the United States is based on its military capabilities and its willingness to use it when necessary. If the United States were to provide the assistance to the world that it does today without wielding its military might, it would possibly find itself the "darling" of the world. If Japan were to take a route similar to this, it may in fact be able to obtain a world status that is unparalleled.

\section{Conclusion}

The current national security strategy of Japan is to rely on its strategic alliance with the United States and its application of the non-military instruments of national power, or specifically that power wielded in the diplomatic, economic and finance arenas. Today, however, a debate is taking place within Japan that has many calling for a change to Article 9 of the Japanese constitution, thus enabling Japan to utilize its military capabilities for purposes other than self defense. I have contended in this paper that Japan should make a change to its national security strategy but only as it relates to the use of non-military power In doing so, I argue that the first step Japan must take is atonement for its past aggressions. This includes working collectively with those countries that it has committed atrocities against in the past and negotiating an agreement on how that history should be remembered. Taking this approach will allow the groundwork to be laid for the development of a peaceful region built on the framework of trust. These steps will enable the development of agreements on the other issues that are affecting Japan's relationships with its neighbors such as the dispute over the Islands in the Sea of Japan/East Sea.

Clearly, Japan should continue to focus on its alliance with the United States as a major part of its overall national security strategy. The benefits that each country receives from this strategic partnership are clear and the fostering of this alliance should not only be a focus for Japan but the United States as well. However, Japan's reliance on the United States for security should not be to the extent that it has been in the past. For defensive purposes only, Japan should continue to develop military capabilities and look to take on an increasing role in its defense. Japan should continue the development of capabilities that are not considered offensive in nature. 


\section{Endnotes}

${ }^{1}$ Lee Hudson Teslik, "Japan and Its Military," April 13, 2006, Council on Foreign Relations; available from http://www.cfr.org/publication/10439/japan_and_its_military.html; Internet; accessed 27 September 2006.

${ }^{2}$ Ibid

${ }^{3}$ Ibid

${ }^{4}$ Hisane Misaki, "Where is Japan Heading?," Japan Focus, November 14, 2005; available from http://japanfocus.org/products/details/1586; Internet, accessed January 11, 2007.

${ }^{5}$ Mari Yamamoto, “Japan's Grassroots Pacifism," Japan Focus , February 24, 2005; available from http://www.japanfocus.org/products/details/2102; Internet; accessed September 27, 2006.

${ }^{6}$ Ibid.

${ }^{7}$ Teslik

${ }^{8}$ Captain Katsutoshi Awano, "Japan's Military Role - Alliance Recommendations for the Twenty-first Century," Naval War College Review LI, no. 4 Autumn 1998 [journal on-line]; available from http://www.nwc.navy.mil/press/Review/1998/autumn/art1-a98.htm; Internet; accessed 27 September 2006.

${ }^{9}$ Ibid.

${ }^{10}$ Ibid.

11 "Japan Defense Agency - Japan Self-Defense Force," available from http://www.globalsecurity.org/military/world/japan/jda.htm; Internet; accessed 27 September, 2006

${ }^{12}$ Andrew Gordon, "The Overthrow of the Tokugawa," in A Modern History of Japan (New York: Oxford University Press, 2003), 17-18.

${ }^{13}$ Ibid, 49-50.

${ }^{14}$ Ibid., 50

${ }^{15}$ Ibid., 50.

${ }^{16}$ Ibid., 50,61.

17 Ibid., 61-70

${ }^{18}$ Ibid., 208

19 Ibid., 208-209.

${ }^{20}$ Ibid., 231. 
21 "The Constitution of Japan," available from http://www.solon.org/Constitutions/Japan/ English/english-Constitution.html; Internet; accessed 27 September 2006.

${ }^{22}$ Fukushima Mizuho, "The Constitution is Japan's Pledge of Peace to the World," January 14, 2006, Japan Focus; available from http://www.japanfocus.org/products/details/1717; Internet; accessed 15 August 2006.

23 "The Constitution of Japan"

${ }^{24}$ Misaki

${ }^{25}$ Lee Wha Rang, "Japan's Military Threat to Korea and China," May 18, 1996; available from http://www.kimsoft.com/korea/jp-mil.htm; Internet; accessed 9 October 2006. Although kimsoft.com is considered to be a biased source towards North Korea, the use of this source in this paper is in cases of generalities towards Japan.

26 "The World Fact Book"

${ }^{27}$ Teslik

${ }^{28}$ Misaki

${ }^{29}$ BBC News, "US Questions Japan's pacifism," August 13, 2004; available from http://news.bbc.co.uk/2/hi/asia-pacific/3561378.stm; Internet; accessed 27 September 2006.

${ }^{30}$ Ibid.

${ }^{31}$ Michael J. Green, Understanding Japan's Relations in North East Asia: Hearings on Japan's Tense Relations with Her Neighbors: Back to the Future, Testimony presented to U.S. Congress, House of Representatives, Committee on International Relations,14 September 2006 , available from http://www.csis.org/media/csis/congress/ts060914green.pdf; Internet; accessed 27 September 2006.

32 Ibid.

${ }^{33}$ Tom Plate, "The Japanese have a Word for it," January 14, 2005, UCLA Asia Institute; available from http://www.asiamedia.ucla.edu/article.asp?parentid=19733; Internet; accessed 27 September 2006.

${ }^{34}$ Green

${ }^{35}$ Ibid.

${ }^{36}$ Tripp Ritter,"U.S. Can Mute Regional Effects of Rearmed Japan," World Politics Watch Exclusive, 11 September 2006; available from http://worldpoliticswatch.com/article.aspx?id= 169; Internet; accessed 25 November 2006.

${ }^{37}$ Ibid.

${ }^{38}$ Ibid. 
39 "Issues: History Textbooks," Memory and Reconciliation in the Asia-Pacific, available from http://www.gwu.edu/ memory/yang/new/issues/textbooks/index.html; Internet; accessed 25 November 2006.

40 Ibid.

${ }^{41}$ Ibid.

42 "Tokyo Trials Poll," Maureen and Mike Mansfield Foundation, available from http://www.mansfieldfdn.org/polls/poll-06-3.htm ; Internet; accessed 24 October 2006.

43 "Public Opinion Survey on Diplomacy by the Cabinet Office of Japan," Maureen and Mike Mansfield Foundation, available from http://www.mansfieldfdn.org/polls/poll-05-12.htm; Internet; accessed 24 October 2006.

${ }^{44}$ Zena Ho, "A New Era, A New Strategy," UCLA International Institute; available from http://www.isop.ucla.edu/article.asp?parentid=34864; Internet; accessed 8 October 2006.

${ }^{45}$ Ibid.

${ }^{46}$ Esther Pan, "Japan's Relationship with South Korea," Council on Foreign Relations, 27 October 2005; available from http://www.cfr.org/publication/9108/japans_relationship_with_ south_korea.html; Internet; accessed 8 October 2006.

${ }^{47}$ Gordon, 206.

48 Ibid.

${ }^{49}$ Pan

${ }^{50}$ Pan

${ }^{51}$ Pan

${ }^{52}$ Karasaki Taro, "Why Japanese Wartime Apologies Fail," May 9, 2005, Japan Focus, available from http://www.japanfocus.org/products/topdf/1794; Internet; accessed 8 October 2006.

53 Ibid.

${ }^{54}$ Ibid.

${ }^{55}$ Pan

${ }^{56}$ Choi Soung-ah, "Seoul summons Japanese envoy (Government stepping up measures against Tokyo on Dokdo dispute)," Korea Herald, February 24, 2005; available from http://www.freerepublic.com/focus/f-news/1350353/posts; Internet; accessed 19 November 2006.

${ }^{57}$ Ibid. 
${ }^{58}$ Green

${ }^{59}$ Green

${ }^{60}$ Green

${ }^{61}$ Antoaneta Bezlova, "China Guards its UN interests," Asia Times, June 16, 2005; available from http://www.atimes.com/atimes/China/GF16Ad01.html; Internet; accessed 27 September 2006.

${ }^{62}$ Foster Klug, "Pentagon Official Warns of Chinese Buildup,"San Francisco Chronicle, 16 March 2006 [newspaper on-line]; available from http://www.sfgate.com/cgi-bin/article.cgi?f=I n/a/2006/03/16/national/w113816S67.DTL ; Internet; accessed 15 December 2006.

${ }^{63}$ Ibid.

64 Ibid.

${ }^{65}$ Ibid.

66 "The World Fact Book"

${ }^{67}$ Esther Pan, "Is China a Regional Military Threat?," October 18, 2005, Council on Foreign Relations; available from http://www.cfr.org/publication/9052/is_china_a_regional_military_ threat.html; Internet; accessed 15 October 2006.

${ }^{68}$ Global Policy Forum ; "Nuclear Weapons Testing," available from http://www.globalsecurity.org/wmd/world/dprk/nuke-test.htm; Internet; accessed 19 October 2006.

${ }^{69}$ Ibid.

${ }^{70}$ Federation of American Scientists ; "Nuclear Weapons Program," Federation of American Scientists , 16 April 2000; available from http://www.fas.org/nuke/guide/japan/nuke/; Internet; accessed 19 October 2006.

${ }^{71}$ The Associated Press, "N. Korea nuclear test plans a threat to peace, Japan says," International Herald Tribune, 3 October 2006 [newspaper on-line]; available from http://www.iht.com/articles/ap/2006/10/03/asia/AS_GEN_Japan_NKorea_Nuclear.php; Internet; accessed 19 October 2006.

72 Yoji Hosoe, and Masaya Suzuki, "North Korea and Japan - Japan's Key to Recover from its Economic Crisis," EDGE spring 2003 [journal on-line]; available from http://www.stanford.edu/class/e297a/North\%20Korea\%20and\%20Japan.pdf; Internet; accessed 8 October 2006.

${ }^{73}$ Sano

${ }^{74}$ Anne Gearan, "Rice Promises U.S. Defense of Japan," Associated Press, 18 October 2006; available from http://www.comcast.net/news/index.jsp?cat=GENERAL\&fn=/2006/10/ 18/501412.html\&cvqh=itn_rice ; Internet; accessed 18 October 2006. 